\title{
EUROPEAN GEOTHERMAL DRILLING EXPERIENCE- \\ PROBLEM AREAS AND CASE STUDIES
}

\author{
G. Baron and P. Ungemach \\ Commission of The European Communitles
}

Belgium

\begin{abstract}
Geothermal drilling has long been restricted in Western Europe to the sole dry steam field of Larderello in Italy. In the last few years, a wider experience is building up as a consequence of intensified exploration and development programs carried out for evaluation and production of both low- and high-enthalpy geothermal resources. A sample of some 40 boreholes indicates the following problem areas.
\end{abstract}

\section{Low-Enthalpy Drilling}

Due to similar settings-hot water system flowing in sedimentary units at temperatures and depths ranging from $40^{\circ}$ to $140^{\circ} \mathrm{C}\left(104^{\circ}\right.$ to $\left.284^{\circ} \mathrm{F}\right)$ and from 1,000 to 3,500 metres $(3,281$ to 11,484 feet), respectively-the technology here is strongly dependent on oil and gas drilling practice. Still, specific problems remain in the areas of multiplereservoir reconnaissance and well completion at production and reinjection levels, particularly in poorly consolidated fluvio-deltaic sequences leading to sand control and swelling clay problems. Expertise needs to be developed to minimize costs, secure high production capacities, long lifetimes, and minimum maintenance compatible with the economics and the lack of suitable workover facilities.

\section{High-Enthalpy Drilling}

Exploratory drilling is currently combining wildcatting and deeper investigations of known fields. Lost circulation, drill string corrosion, tubulars, mud, cementing, and deviation control are the most frequently encountered difficulties while drilling in hostile waterdominated environments. Formation temperatures in excess of $300^{\circ} \mathrm{C}$ $\left(572^{\circ} \mathrm{F}\right)$ are often the rule, and recent drilling conducted in volcanic areas have hit fluids approaching supercritical state. Whenever these problems do not remain under control, they result in rig standby and extra costs which severely penalize an industry which needs sharp improvements to be fully reliable and cost effective.

Geothermal well stimulation is therefore a field of growing interest, but it lacks adequate procedures.

Current geothermal drilling practice in Europe -is illustrated by three typical case studies. 


\section{DISCLAIMER}

This report was prepared as an account of work sponsored by an agency of the United States Government. Neither the United States Government nor any agency Thereof, nor any of their employees, makes any warranty, express or implied, or assumes any legal liability or responsibility for the accuracy, completeness, or usefulness of any information, apparatus, product, or process disclosed, or represents that its use would not infringe privately owned rights. Reference herein to any specific commercial product, process, or service by trade name, trademark, manufacturer, or otherwise does not necessarily constitute or imply its endorsement, recommendation, or favoring by the United States Government or any agency thereof. The views and opinions of authors expressed herein do not necessarily state or reflect those of the United States Government or any agency thereof. 


\section{DISCLAIMER}

Portions of this document may be illegible in electronic image products. Images are produced from the best available original document. 
Prior to 1974 geothermal energy (GE) was more or less regarded by European (EC) States an exotic curiosity of marginal impact although, not mentioning Roman ages, at least two countries had. Long been involved in geothermal matters - Italy in power generation from dry steam sources (Larderello, 1904) and France in direct use of low enthalpy aquifers (Melun L'Almont district heating doublet, 1969).

In the $1960^{\prime}$ 's ENEL, the italian power agency, who had built up its drilling and production experience on the Larderello field, extended exploration to other areas of Tuscany and Northern Latium. This led to the discovery of the Travale and Monte Amiata dry steam and the Cesano pressurized water systems.

Since then, and as a consequence of the energy price crisis, EC countries revisited $G E$ and a pronounced involvement could be noticed. In particular a $R \& D$

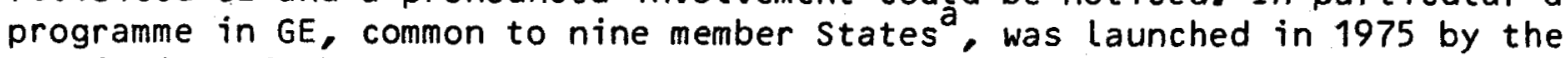
Commission of the European Communities (CEC) adressing all aspects of geothermal research, from exploration to production, in which wildcatting took an important part (8).

In spite of a very recent activity in drilling for low grade heat and in active volcanic areas, the european geothermal well record is not negligible as shown in Table 1. It provides already a suitable data base for reviewing major problem areas, associated with exploration and production drilling, with respect to (i) drilling and completion technology, ( $i$ ) environmental constraints and ( $i i j$ ) economics.

For the sake of simplification, drilling is divided according to the enthalpy of the geothermal fluid, as drilling of high and low enthalpy wells adresses in fact contrasted geological and thermal environments and different usage and economics.

Three case studies, selected among deep exploration projects supported by the CEC, will illustrate the practical problems encountered in geothermal drilling.

\section{GEOTHERMAL ENVIRONMENTS}

The geological structure of Europe and consequently its geothermal environments are commanded by the geodynamic evolution of the Eurasian Plate. It displays a variety of geodynamic settings, most plate tectonic attributes being present except the oceanic crust. Western. Europe at large is an area of old and rigid continentat crust characterized by crystalline massifs, intracratonic and foredeep basins and continental rifting. A younger crust stretches over the Mediterranean area, where the African and Eurasian Plates collide, exhibiting typical features - subduction, marginal basins, island arcs and extensional horst and graben systems.

"Belgium, Denmark, Federal Republic of Germany, France, Ireland, Italy, Luxembourg, The Netherlands, United Kingdom. Greece will join the EC in 1981. 
These environments are irregularly distributed though. An important consequence is that the majority of EC states are faced with the sole low enthalpy outlook, high enthalpy sources being limited to Central and Southern Italy and to tastern Greece.

Fig. 1 displays, at a broad scale, the EC geothermal resource status with indication of the areas where a commercial development can be reliably envisaged. Three main systems can be characterized, respectively:

- Low enthalpy resources which prove to be prolific and dependable in foredeep and intracratonic basins wherever they develop regional aquifer units. Such large sedimentary multi-aquifer systems are found in France (Aquitaine and Paris Basins), Italy (Po Valley), United Kingdom (Wessex, East Yorkshire and Northern Ireland Basins), Germany (Southern Molassic Alpine foredeep and Northern Munsterland), Holland and Denmark. .

- continental rifting and central, recent but extinct volcanism which stand half way between high and low enthalpy resources. Here, an association of often high temperatures $\left(100\right.$ to $160^{\circ} \mathrm{C}$ ) and of complex reservoir and heat source conditions renders exploration delicate. Rift valleys (Limagne, Rhone Valley and Rhine Graben) exhibit intense compartmenting requiring sophisticated seismics, structural analysis and tectonics as to identification of active faulting and porosity patterns.

- high enthaly reservoirs placed along the mediterranean belt, chiefly the Tuscanian distensive tectonic system, the Northern Latium and Campanian plioquaternary volcanism and the subduction magmatism of the Eolian Arc.

\section{DRILLING DATA BASE}

Over 800 wells have been drilled in Western Europe for geothermal purposes, since the early $1900^{\prime} \mathrm{s}$, with a success ratio of $56 \%$ close to the world average. Note, in Table 1, that for the Larderello field the success ratio is decreasing in the past four years with increasing drilling depths. Low enthalpy drilling, which often consists of drilling a well pair, the so called geothermal doublet, for conservative and environmental reasons is still in its early development stage. Future developments - about 400 wells scheduled in the next five years, should the rig and manpower be available - should markedly improve this ratio. Two areas of the EC are already, or likely to be, intensely drilled. One is the Larderello field with the high well concentration depicted in Fig. 2. It is obvious that effective well stimulation techniques would significantly improve the economics of the exploitation of this fracture dominated field. The second is the Paris outskirts, showll in Fig. 3, where some 60 planned doublets emphasize drilling, work over and related environmental implications in urban areas. 
Most of the oil and gas drilling background is transferable to hot water drilling which requires a similar technology owing to a similar environment aquifers flowing in sedimentary rocks at depths and temperatures varying from 40 to $140^{\circ} \mathrm{C}$ and 1000 to $3500 \mathrm{~m}$ respectively. Still, there are a few striking differences in the areas of well completion, reconnaisance, drilling fluids, environmental constraints and, of course, economics.

Basically, low grade heat being of low market value is not yet transportable economically over distances greater than $5 \mathrm{~km}$. Drilling costs, elsewhere, are high (see Table 2) - twice the North American figures - because of a shortage of inland rigs and of the competition with hydrocarbon exploration programmes. In 1981, a cost of 2 million US \& for a $2000 \mathrm{~m}$ deep well tends to become the rule all over western Europe. As a result (i) high well productive capacities, say $100 \mathrm{~m} 3 / \mathrm{h}$ or $15,000 \mathrm{bbl/d}$ for a commercial hole by 1980 standards are required to ensure a decent return on investment; which ( $i$ i) implies significant heat loads in the vicinity of the well source - tenths of thousands Gcal./year - which (iii) bounds development to district heating of large cities.

\section{Well Completion}

A major difficulty in geothermal energy is the adequate cementing of columns including liner hangers, a problem with which one has to live.

Most carbonate geothermal reservoirs are produced (and injected) in open hole - Dogger in the Paris Basin, carboniferous karstified limestone in Belgium and createceous dolomite in Aquitaine - and exhibit, due to their fracture dominated porosities, high yields.

Triassic clastic deposits (sandstone and interbedded clay) are less dependable reservoirs because of random porosity trends (compaction, diagenesis) and require suitable well completion. The rule, below $1500 \mathrm{~m}$, is to avoid the placement of a gravel pack which is considered a too risky operation. A good substitute, already experienced in underground gas storage, is to set down hole wire wrapped screens of either oil and gas or superweld type (). A classical design would be a $\varnothing 6$ " 5/8 stainless $316 \mathrm{~L}$ superweld screen, with a $0.8 \mathrm{~mm}$ slot, on a well producing from a sand and sandstone matrix. No sand cortrol problems have yet appeared.

Reinjected fluids being cooled formation fluids, circulated under pressure, fluid compatibility, swelling clay and precipitation problems are minimum to date.

Multi Aquifer Reconnaissance

In the center of the Paris Basin coexist the possibility of producing either the Dogger or the Trias reservoirs. The Dogger is a reliable open hole producer but is cooler whereas the Trias is hotter but random as to porosities and moreover it requires a completion. Only direct assessment by testing can optimize this balance. There are three possible strategies :

i. Target reservoir : Trias

ii. Target reservoir : Dogger

Produced reservoir : Trias

iii. Target reservoir : Trias

Produced reservoir : Dogger

Produced reservoir : Dogger 
$i$ and $i j$ pose no problem. In case situation $i j i$ was encountered the design depicted in Fig. 4 has been suggested and agreed on.

It consists, in brief, of the following sequence :

- Well drilled to the basement, TD: $2000 \mathrm{~m}$ (vertical)

- Testing of the Dogger

- No cementing of the 9 " $5 / 8$ casing in the Dogger in order to produce it should the Trias exhibit poor reservoir performance. To prevent casing corrosion by Dogger brines a thixotropic gel ("Ken Flow") is placed by means of a DV stage cementer.

- Testing of the Trias

- Plugging the hole by a cement plug set below the Dogger.

- Opening of the Dogger window either by perforating the 7 " liner or by milling and extracting after pulling out the liner hanger.

- Production of the Dogger by releasing the "Ken Flow" through perforations or the 8 " $1 / 2$ open hole after pulling out the 07 "liner.

- The 9" 5/8 becomes the reinjection column.

- Drilling of the production borehole, objective Dogger.

Caving and stuck drill pipe

In the Paris Basin (see a typical geological log in Fig. 5) a major drilling problem arises when crossing the Kimmeridgian. This formation, some $150 \mathrm{~m}$ thick, composed of alternating carbonate and clay streaks causes, if drilling parameters are not perfectly adjusted, caving and subsequent sticking. This proves cumbersome, particularily in slant drilling required by geothermal doublets. It soon appeared that light muds with low solid content were the solution. Therefore, oil based muds were substituted to the routinely used bentonitic muds. Fig. 6 clearly shows the improvement brought by oil based muds on borehole geometry. Adequate mud cleaning facilities at surface keep environmental problems to a minimum (less than $3 \%$ oil content in cuttings).

\section{Oil Based Muds}

In general, reluctance is frequently noticed among professionals towards using oil base muds despite their many advantages, principally because of environmental (disposal and fire) and economical considerations.

In one case use of these muds is reported satisfactory ( 9 ) during most of the drilling sequence. The site constraints were such - urban area, little available space, target formation distant from the drilling platform - that it was necessary to drill in a $88^{\prime \prime} 1 / 2$ diameter at a $40^{\circ} \mathrm{drift}$ angle with light muds (density of $1.04-1.05)$, no reserve pit and no pollution of the environment.

oil based muds were found to best meet these objectives by their ability to (i) secure fast drilling rates by minimizing friction and sticking risks associated

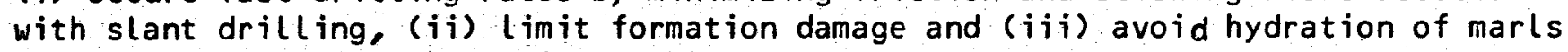
and related swelling and caving problems.

The implications were threefold $(i)$ to keep density under control by avoiding discharge, ( $i i)$ to limit mud losses when removing solids and $(i j)$ to reduce significantly treated and waste volumes. This emphasizes solid treatment. A rather standard mud cleaning device was added to the mud circuit sketched in Fig. 7 . 
It enabled to remove $54 \%$ of the solids and to recover $89 \%$ of the emulsion of the desilter heavy effluents. Drilling could be completed in 20 days from 200 to 1330 with less than $5 \%$ redrilling time, and below the projected budget. Density was always kept at 1.05, with a total mud volume of $200 \mathrm{~m} 3$ and a percentage of removable drilled solids equal to $67 \%$. Moreover no pollution is reported.

Noise

Conventional, non electric, petroleum rigs used in geothermal drilling can generate noise up to $85 \mathrm{dbA}$ whereas legal environmental regulations set the limits in urban areas, with heavy traffic, to $45+15=60 \mathrm{dbA}$ and $45+5=50 \mathrm{dbA}$ during day and night time. Excess noise margins are of 5 and $3 \mathrm{dbA}$ respectively.

Waiting for electricity driven rigs, temporary measures can achieve the objective of drilling at tolerable noise levels. They consist, among others, of: :

- suppressing generator sets, replaced by connections to the grid,

- orienting the drilling platform and noisy engines according to the direction of dominant winds,

- setting mufflers and hoods on engines,

- building anti-noise walls, batters or wooden screens,

- avoiding noisy operations at night : stem manoeuvers, cementing, logging.

They result in additional costs estimated at 100,000 US 8 .

$0 i l$ and gas drilling practice versus geothermal reservoir evaluation

The following case study (6) may well illustrate the problems likely. to be encountered when applying straight forward petroleum routine to geothermal exploration.

Type of well : wildcat.

objective : evaluation of hot water bearing formations inferred in Triassic fluvio continental deposits; reservoir rocks = sand, sandstone, interbedded clay.

Predicted down hole characteristics : $T D=3000 \mathrm{~m}, B H T=130-150^{\circ} \mathrm{C}$, pressure $=$ hydrostatic.

Location : populated suburban district, optimized by a vibroseismic survey.

Regional background knowledge : previous hydrocarbon exploration and production drillings, some $20 \mathrm{~km}$ apart, and playback of a continuous seismic coverage enable the geology of post-7riassic terrains to be retiably assessed.

Technical column : $13 " 3 / 8$ casing $(1200 \mathrm{~m}), 0$ 9" $5 / 8$ liner $(1100-1900 \mathrm{~m})$, 0 7" Liner (1800-2600 m) - Reservoir : either open hole, wire wrapped screen (0 4" 1/2) or slotted liner ( 4" 1/2).

Mud programme : bentonitic, bentonitic + lignosulfonate and baryte, saturated brine.

The outcome was the following :

Predicted and actual figures stand in rather close agreement as to TD (3200 m), temperature $\left(140^{\circ} \mathrm{C}\right.$ ) and formation pressure. Reservoir top is hit at $2700^{\circ} \mathrm{m}$ and a net pay of $150 \mathrm{~m}$. is assessed from the CNL-BHC porosity cross plot (cut-off porosity : $8 \%$ ). 
Major events : incomplete cementing of the $13 " 3 / 8-9 " 5 / 8$ liner hanger. At $2000 \mathrm{~m}$ a mini eruption of oil and dissolved gas is controlled by the crew. It causes a strenghtening of safety regulations : well head change and ant $i-e x p l o s i v e$ modifications brought to the rig. Drilling resumes with a bentonite lignosulfonate mud of density 1.13 at reservoir top ( 1.08 for hole control and cutting recovery, 0.05 for 5 bars/1000 m over pressure control). Total lost circulation at $2850 \mathrm{~m}$. Mud Losses : $185 \mathrm{~m} 3$. After control, drilling progresses to TD with a bentonitic mud (d: $1.03-$ 1.04). Mud losses : $290 \mathrm{m3}$. An acid frac job is performed and a $600 \mathrm{~m} 4$ " $1 / 2$ slotted liner set down hole before move-out. Number of cores : three (top reservoir - basement). Number of casing DST's : 3 (first : dry, second : productive; third over total open hole section : less productive).

Diagnostic : reservoir plugged by a bentonic mud in a hot $\left(140^{\circ} \mathrm{C}\right)$ aquifer environment; unsufficient reservoir reconnaissance; no further reservoir investigations possible (flowmeter, side wall coring) owing to a nonremovable slotted liner. Failure reasons are three fold': blow out fears, inadequate mud, budget limitations. The first caused denser drilling fluids and exaggerated hole control, the second resulted in formation damage, the third in a funnel shaped column the cheapest mud formula and too fast drilling rates at reservoir level.

Consequences: side track from reservoir top, with saltwater as a drilling fluid and a modified hole geometry (7" casing tied back to the former 7 " -9 " $5 / 8$ liner hanger). Subsequent extra costs are estimated at $1.2 \mathrm{mill}$ ion US 8 .

\section{HIGH ENTHALPY DRILLING}

General

For many years high enthalpy drilling was bound to Tuscan dry steam fields and it is only recently that more diversified settings have entered the geothermal drilling and production picture. of the 814 wells drilled at temperatures above $150^{\circ} \mathrm{C}$ about 30 , drilled in the past decade, dealt with water dominated systems. Relevant environments can exhibit formation temperatures in excess of $400^{\circ} \mathrm{C}$ and a bottom hole temperature of $300^{\circ} \mathrm{C}$ is a quite common figure. $\mathrm{CO}_{2}$ contents as high as $80 \%$ are somet imes noticed in the early producing stage (Torre Alfina). Reservoir rocks include: quartzite, phyllite and anhydrite (Larderello, Travale, Monte Amiata, Pian Castagnaio) - Carbonate (limestone and dolomite) rocks (Larderello, Travale, Torre Alfina, Cesano, Latera) - alkaline tuffaceous products (Mofete, San Vito) - micaschists, crystalline and metamorphic rocks (Milos). But in general it is less the nature of the rock than its fractured porosity, the dominant feature of geothermal reservoirs, which is a problem. Hard and abrasive rocks are drilled at decent rates with conventional tools. Lengths of 75,100 and even $125 \mathrm{~m} \mathrm{dr} i$ lled with the same tool are not uncommon in geothermal bit records. It is more a matter of tool to formation adequacy than of adequate tool availability.

Fractures, especially wher, massive as in the Larderello field, associated with high temperatures cause the major problems as to lost circulation control, cement ing jobs and setting of multiple casings These difficulties are the major reasons to the twofold increase of geothermal drilling costs as compared to equivalent oil and gas operations. Statistics, carried out on a sample of 20 wells drilled at depths of 1000 to $1500 \mathrm{~m}$ with similar technologies show (Munier Jolain, personal communication, 1980), for hydrocarbon versus geothermal : total duration (days) 30/50, 
effective drilling time $(\%) 35 / 20$, tool. Lifetime identical, control (losses, cementing...) and instrumentation (\%) 13/30.

Although lost circulations are not to be overlooked (see example further) they are usually kept under control by cement plugs - up to 17 are reported on a job at $120 \mathrm{~m}$ depth. So cementing is the major puzzle especially when considering that squeeze and stage cementing are ruled out in geothermal wells. A rule frequently adopted consists of placing three successive columns $\left(17^{\prime \prime} 1 / 2-13^{\prime \prime} 3 / 8-9^{\prime \prime}\right.$.5/8 7") continuously, cemented but not recessarily over the entire length, with expansion spools at well head. Slotted liners are more a makeshift than a need. A standard cement utilized in the $E C$ is the Italcement $i$ leotherm Class $G$ cement, based on $40 \%$ Silica flower which copes with temperatures of $300^{\circ} \mathrm{C}$ using adequate additives and retarders ( 4 ).

A typical high temperature well is shown in Fig. 8 . Here at Latera ( 7 ) in a volcano sedimentary context, ENEL utilized a mud based on a sepiolite-bentonitechromo-lignite formula with XP20 Resinex resin additives and polyacrylates. Other mud formulae used in Italy are (4) : asbestos-fiber muds pretreated with chromolignites and non-ionic surfactants; bentonitic muds with $\mathrm{FCL/CL}$ stabilized by Synergetic Polymer Blend; bentonitic muds with high ferro-chromo-lignosulfonatel chromo-lignite contents, protected and stabilized by asphaltic oil dispersed products.

It can be seen in Fig. 8 that a significant set of conventional wireline logs were ran down hole. In general high temperature do not cause major problems provided there is adequate cooling. Some logging companies claim temperature tolerance up to $260^{\circ} \mathrm{C}$ for main tools but these limits were not checked in hole in EC wells. As to bottom hole measurements Ameradas and preferably Kuster mechanical devices modified for high temperature service, are found the most reliable and have been used up to $370^{\circ} \mathrm{C}$ over several hours. Single shot instruments mounted on ther$\mathrm{mal}$ shields have proved effective at $400^{\circ} \mathrm{C}$ and 1.5 hours, (4). Open hole packers have failed after 12 hours operating in a $200^{\circ} \mathrm{C}$ environment in the Phlegreaen fields. Down hole high temperature hardware is being developed with the support of the $\mathrm{EC}$ in the following areas : pressure and temperature gauge $\left(300^{\circ} \mathrm{C}, 500\right.$ bars), flowmeter-caliper $\left(240^{\circ} \mathrm{C}, 250\right.$ bars), fluid sampler $\left(240^{\circ} \mathrm{C}, 250\right.$ bars). Research is also conducted for the design of an in hole optical fiber principle for power and signal transmission A logging facility with a $4000 \mathrm{~m}$ Teflon insulated cable is currently operating in Italy.

In Europe a high enthalpy well is considered commercial for a net productive capacity of $1.5 \mathrm{MW}$. Costs of geothermal wells sunk at depths of 2000 and $2500 \mathrm{~m}$ average 1.9 and $2.8 \mathrm{mill}$ ion US 8 respectively. Slim hole (projected not actual) costs for similar depths amount to 500,000 and 650,000 US 8 . Environmental constraints may add $30 \%$ to the bill (Campi Flegrei).

According to joint AGIP and ENEL calculations (Ceron, personal communication, 1979 ) the structure of geothermal mining costs is divided as follows ( $50 \%$ versus $70 \%$ success ratios in percentage of total mining cost) : surface exploration $(1.5 / 2)$, deep drilling $(77.5 / 70)$, reservoir engineering $(9.5 / 14)$, production engineering (9.5/13), disposal (9/11). 
New tendancies are shaping in high enthalpy exploration drilling. Slim hole wildcats progressively replace the so called shallow gradient holes utilised in the past for heat flow mapping purposes. These slim holes, drilled essentially on geophysical indices down to depths of $2000 \mathrm{~m}$ with a 6 6" terminal open hole diameter, are shown to be three times cheaper than an ordinary exploratory borehole. They are not designed as production wells and their use is therefore restricted to geological reconnaissance, pressure - temperature measurements and reservoir evaluation. As a result, slim hole wildcatting should enable, (i) to speed up exploration, (ii) to cut down exploration costs, ( $i i j)$ to calibrate geophysics and derive relevant conceptual models and, therefore, (iv) to reduce speculations. Slim holes are currently being drilled or planned in the near future on the following prospects : Somma vesuvius (Ottaviano permit, Campania, Italy), Sabattini and Cimini (Northern Latium, Italy) and Mont Dore (Massif Central, France) (8).

\section{Deep drilling case studies}

In known and recently discovered fields, deep drilling (below $3000 \mathrm{~m}$ ) aimed at investigating the entire reservoir sequences, is becoming systematic. This procedure, although it poses severe problems associated with higher temperatures and drilling through successive producing layers; is necessary with respect to optimisation of future production and reservoir management. It is also the best possible substitute of past mining practice of taking the best part of shallower producing horizons.

Two wells drilled recently in Italy defended this concept.

A first one was drilled at Sasso in order to explore the deeper parts and locate the water phase of the long exploited Larderello dry steam system which is presently being produced in the upper carbonate reservoir formations (see $\log$ in Fig. 9). Target depths of $4500 \mathrm{~m}$ were estimated, based on the following arguments, (i) the presence of a regional, continuous and energic seismic reflector and, ( $i$ ) source temperature of $350^{\circ} \mathrm{C}$ inferred from gas geochemistry which attributed a deep origin to $50 \%$ of the gasses trapped in the upper field. As a whole this project ought to be regarded as a combined exploration and drilling technology research venture.

The second well has just been completed at San vito, in campi flegrei, a pressurized water system developing in an active volcanic context (see map in Fig. 11)(5). Here the objective was to step out of the Mofete block, at present in the evaluation stage, and to investigate the adjacent and lower compartment close to a normal fault trending radially to the Pozzuoli caldera. A depth of $3000 \mathrm{~m}$ was assigned to the San Vito hole against $2000 \mathrm{~m}$ for the deepest well in Mofete.

The Sasso 22 deep drilling

Two drilling phases can be distinguished, namely:

- first, the crossing of the upper producing reservoirs which ended after one year with the setting and cementing of the 09 " $5 / 8$ casing. This phase is dom inated by lost circulation (see Fig. 9 ). 
- second, the drilling below $3000 \mathrm{~m}$, in a harsh environment as to rocks and temperatures. It is characterized by lost circulation, tool deviation, drill pipe corrosion, breakage, fishing and side tracking (see.Fig. 10). It lasted eleven months.

If phase one could well be regarded as one eyed, phase two was definitely blind. To our knowledge, very few wells, if any, have exhibited so many difficulties and hardware failures at the same time (2).

Starting from $608 \mathrm{~m}$ the hole was drilled in total lost circulation using plain water as a drilling fluid with viscous plugs pumped in at each stem move. Lost circulation is caused by Large fractures and cavities and cannot be controlled neither by chemical - plugging agents - nor mechanical - bento block - means. Consequently, no return circulation being possible, the cuttings are not recovered and little stiffening is applied to the drilling string. As a matter of fact no stabilizers could be used. Still, tool blocking, stuck drill collars and breakage of bottom hole assemblies were sometimes noticed but remained under control. In particular, the injection of cold water and its subsequent shrinkage proved effective in getting unstuck.

Cementing, with stinger, of the 9" $5 / 8$ casing could not be achieved over the required length, regardless of the often ambiguous indication of the CBL, 'Owing to the presence of several fissured absorbing horizons. So, perforating and squeeze were necessary.

0therwise, the bit record proved satisfactory with average 50 hours and 95 meters figures and the following wireline logs could be run : HRT - BHC - GR $D L L$ - BHC - LS - C and flowmeter.

Below the 9" $5 / 8$ casing shoe the presence, in addition to important lost circulations hit at $3000 \mathrm{~m}$, of hard and highly heterogeneous metamorphic rocks gneisses and amphibolites - caused the deviations and severe dog legs displayed in Fig. 10. In conjunction with high temperatures, corrosion was another puzzle. Breakage of drill pipe often occured and even several ring elements of the annular BOP were found down hole. Frequent fishing jobs took place which, owing to bottom hole temperatures in excess of $350^{\circ} \mathrm{C}$, could not call upon explosive and hydraulic (back off, bumper sub, etorecovery techniques. When fishing failed and deviation drifts showed excessive side tracking was the rule. Placing of cement plugs, to keep the whipstock stationary, not being possible, short cuts were required to side track without reentering the hole. After a first failure to deviate from the first side track (see Fig. 10), a second whipstock based on a conventional design was manufactured by a service company. After positioning down hole a taper mill opened a one meter long guide hole for the bit. Then combinations of insert bits and of various bottom hole assemblies enabled to pass the fish and continue drilling until a depth of $4094 \mathrm{~m}$ was reached thus establishing a new record in geothermal drilling.

Finally, the persistance of this hostile environment caused the well to be abandoned soon after a third side track had been attempted. The 9" 5/8 casing was in so bad shape after many string anoeuvres and shocks in an empty space (down to $2200 \mathrm{~m}$ ) that the well had to be plugged. Further analyses of samples of tubulars recovered down hole proved that stress corrosion had been aggravated by the use of steam condensates, from the nearby geothermal power plant, as a drilling fluid. 
However, the outcome of this deep drilling venture was not negligible. From a geothermal stand point it proved that a second reservoir was developing down to a depth of $3800 \mathrm{~m}$. Over one million $\mathrm{m} 3$ of water were injected which demonstrated the high absorption capacity of the fractured basement rocks. Core analyses led also to a refined scenario of the temperature history of the Tuscan geothermal field. Paragenesis study showed, in particular, a high temperature event associated with anatectic magmatism followed by a recent hydrothermal activity. As far as drilling technology is concerned, the major conclusions can be summarized as follows:

- deviation control is absolutely vital in these environments. In no way are high temperatures an obstacle to standard single shot operating provided the injected water cools down the hole to the required level.

- it is recommended that future jobs in similar conditions make use of non stabilised heavy drill collars (Uranium, Tungsten) to prevent excessive deviations.

- side tracking over $350^{\circ} \mathrm{C}$ cannot rely on cement plugs, neither on diamond bit which totally failed nor on turbines.

- new specifications as to tubular, well heads, BOP's and particularily seal requirements and inspection are urgently needed for high temperature operation.

- chemical composition and agressivity of injected waters should be carefully tested with respect to stress corrosion.

Incidentally this drilling triggered two research projects, adressing, (i) the design and testing of a mechanical device to beat lost circulation in extensively fractured media and, $(i j)$ the implementation of light weight $(d \leq 1.5$ ) geothermal cement slurries.

The San Vito Well (1)

This exploratory hole drilled by AGIP, operator of an ENEL-AGIP joint venture, with an IDECO super $711 \mathrm{rig}$, is a good example of the problems encountered while drilling in a very high temperature volcanic environment, which required two major instrumentations.

Drilling of the upper 2000 meters proved relatively easy as it benefited from the experience acquired while drilling the three previous wells at Mofete (see location in Fig. 11), sunk at similar depths. In particular, it can be noticed from Fig. 12 that a substantial set of wireline logs could be run down to $2200 \mathrm{~m}$, by adequate cooling.

A first fishing job was attempted at a depth of $2330 \mathrm{~m}$ (see Fig. 13) to recover the bottom hole assembly. After several unsuccessful trials the fish is abandoned down hole.

The well is then side tracked in the open hole section, just below the 9 "' $5 / 8$ casing shoe (Fig. 13). Drilling continues down to $2488 \mathrm{~m}$. Here, further to the stopping of circulation the mud is gelled and coagulates. The release of the assembly is attempted by sending a $\emptyset 1^{\prime \prime} 1 / 2$ scallop gun down the string to perforate and reestablish circulation. It fails because the high temperatures building up in hole decompose the explosive charge. A second trial with a coiled tubing ( $22 \mathrm{~mm}$ ) also fails. 
Again, the bottom hole assembly is left down hole and a back-off is planned in a shallower horizon $(2013 \mathrm{~m}$, some $30 \mathrm{~m}$ above the 9 " $5 / 8$ casing shoe) where lower formation temperature could secure the operation. The job succeeds and the assembly is released but 395 m of $\emptyset 6 " 3 / 4$ drill collars remain at bottom hole.

A second side track is completed by milling the $9 " 5 / 8$ casing, over a length of $25 \mathrm{~m}$ (between 2025 and $2050 \mathrm{~m}, \mathrm{Fig}$. 12), utilising a positive displacement motor and a 1030 " bent sub. After 5 days of operation drilling resumes and progresses down to $2500 \mathrm{~m}$ where the $7 "$ slotted liner is set. Drilling continues in 06 " to $3045 \mathrm{~m}$ (TD). A deviation of $5^{\circ}$ is measured, the return mud temperature being stabilised at $100^{\circ} \mathrm{C}$.

Bottom hole temperatures were recorded on an Amerada gauge at $2500 \mathrm{~m}$ and reached $301{ }^{\circ} \mathrm{C}$ after 43 hours. At total depth, after one week, BHT could not be measured anymore with standard equipment and a temperature of $419^{\circ} \mathrm{C}$ was inferred from the melting of a zinc sample.

The well was then killed after a short production test showed rapid increases in temperature at the well head, not rated for temperatures in excess of $300^{\circ} \mathrm{C}$. A new well head is being designed to cope with temperatures of $400^{\circ} \mathrm{C}$ and pressures of 220 bars and also the presence of $\mathrm{CO}_{2}$. Environmental considerations - the well is drilled in an active volcanic and occasionaly densely populated area - require drastic safety and monitoring regulations before any production test be undertaken. There are also strong expectations that the geothermal fluid is in a supercritical state which has obvious implications on both production and reservoir physics.

Experience gained during drilling can be summarized as follows:

i - mud can be used as a drilling fluid provided it is designed for high temperature usage.

ii - at San Vito, muds contained attapulgite (or sepiolite) suspended in a polymer solution with $\mathrm{KCl}$ as a swelling inhibitor in a tuffaceous alkaline rock context.

iij - mud density ought to be increased and kept as close as possible to the 1.15 target, taking into account losses.

iv - keeping the mud below $100^{\circ} \mathrm{C}$, and preferably around $90^{\circ} \mathrm{C}$, is essential. It is achieved by rapid circulation and by a cooling facility (tower) at surface.

$v$ - Lost circulations, after deduction of evaporation losses occuring in the cooling tower, must be carefully monitored and whenever they exceed the $2 \mathrm{~m} 3 / \mathrm{h}$ threshold a cement plug is to be set down hole.

$v i$ - it is necessary, by all available means, to shorten interruptions of circulation and to carry out partial circulation during manoeuvers.

vij- utilisation of jars, bumper subs and float valves above the tool are strongly recommanded to avoid sticking.

viii - stabilised rotary bottom hole assemblies are necessary.

ix - periodical cleaning of drill pipe is mandatory to optimize circulation. 
This work forms part of the first and second $R \& D$ programmes on alternative energy sources (subprogramme Geothermal Energy) sponsored by the Commission of the European Communities, Directorate General for Research, Science and Education.

The authors are indebted to the Geothermal divisions of ENEL (UNG), AGIP SpA., BRGM, Geoservices Hydrologie and Elf-Aquitaine and in particular to Mr Messeti, Concas, Gimenez, Leandri, Munier Jolain and Vathaire for stimulating discussions on various aspects of geothermal drilling and production.

\section{REFERENCES}

${ }^{1}$ AGIP S.P.A., 1980. Mofete 1 and 2 wells. Final Report, San Donato Milanese, 30 June, 1980. EC contract GE 01/79, 23 p., 15 fig., 9 tab.

2Baron, G., 1980. Commentaires sur le Forage Géothermique Sasso 22 d'Exploration Profonde du Champ de Larderello. Contrat CEE 627-78 EGI. Rapports de Missions du 18-19/4/79 et du 27/02/80 (Unpublished).

Bertini, G., Gianelli, G., Giovannoni, A., Puxeddu, M., Stefani, G.C. and Squarci, P., 1980. Deep Exploration of the Larderello Field. The Sasso 22 Drilling Venture. In : A.S. Strub and P. Ungemach (Editors), Advances in European Geothermal Research, Reidel Pub. Co., Dordrecht, pp. 303-311.

${ }^{4}$ Cataldi, C., 1980. High Temperature Drilling and Hardware. A Contribution to the Hot Dry Rock Working Party. Commission of the European Communities. Brussels, 22 May, 1980 (Unpublished).

${ }^{5}$ Cioppi, D., Ghelardoni, R. Pauci, G., Sommaruga, C. and Verdiani, G., 1980. Demonstration Project. Evaluation of the Mofete High Enthalpy Reservoir (Phlegreaen Fields $\lambda$. In : A.S. Strub and P. Ungemach (Editors), Advances in European Geothermal Research, Reidel Pub. Co., Dordrecht, pp. 291-302.

${ }^{6}$ Elf-Aquitaine, 1980. Rapport Technique de $F$ in de Sondage de Cronenbourg (Well Completion Report). Permis de Strasbourg Geothermie. Mission France, Service Forage MF/PRO No 80.678. Boussens, 10 october, 1980. EC contract 626-79-EGF.

7 ENEL (Unità Nazionale Geotermica), 1980. Latera 1 Exploratory Well (Northern Latium). Final Report, Pisa, April, 1980. EC contract 571-78-1-EGI. 13 p., 7 fig., 8 tab., 2 ann. (Well Completion Report).

8ngemach, P., 1980. From Exploration to Production the Geothermal Case. An Insight to the First $R$ \& D Programme of the European Community. Paper presented at the 7 th annual meeting of the European Geophysical Society. Budapest, 24-29 August, 1980. In press.

${ }^{9} V_{\text {athaire, J.C., Garcia, C. and Bouvier, A., 1979. Nouveaux Développements en }}$ Matière de Traitement des Solides des fluides de Forage. Forages, Revue de l'A.E. M.S. - I.F.P., $85: 49-67$. 
EC Geothermal Well Record

\section{Geothermal fields}

Temperature above $150^{\circ} \mathrm{C}:$

\section{Italy}

- Larderello (1904-1976)

- Larderello (1976-1978)

- Monte Amiata, Pian Castagnaio

- Travale, Radicondoli

- Torre Alfina, Cesano, Vico, Latera

- Vutcano, Sciacca, Mofete, San Vito

- Viterbo, Campi flegrei, Ischia (1940-1960)

Number of Wells drilled productive

$\frac{\text { Success Ratio }}{\%}$

\section{$\%$ Characteristics:}

Typical cost figures of a geothermal district heating scheme

Greece

- Milos

Total High Enthalpy

$\begin{array}{rr}513 & 338 \\ 66 & 33 \\ 63 & 38 \\ 39 & 20 \\ 19 & 10 \\ 7 & 5 \\ 105 & 5\end{array}$

\section{${\underline{T e m p e r a t u r e ~ b e l o w ~} 150^{\circ} \mathrm{C}}^{(*)}$ :}

\section{France}

- Paris Basin

- Aquitaine

- Limagne

- Rhine' Graben

Germany

- Rhine Graben

Denmark

- Danish Basin

Belgium

- Hainault

Italy

- Po valley

United Kingdom

- Wessex Basin

(*) including reinjection wells and wildcats
Total depth :

Production rate :

Bottom hole temperature :

Heat load :

oil savings :

Total cost (1981) :

38
33
38
20
10
5
5

2
451

\section{Prilling}

Products, services

Power

1800 m (2 vertical holes)

$125 \mathrm{~m} 3 / \mathrm{h}$

$94{ }^{\circ} \mathrm{C}$

2000 equivalent dwellings, each 185 m 3 2500 TOE's yearly

6 miltion US 8

Tubulars, well heads, primary circuit piping 1140

Pumping (production, reinjection, feed) 240

Process engineering

Cost $(1,000$ US 8)

1380

$\underline{x}$

450

23

Total subsoil investment

Surface equipment ${ }^{(*)}$

$P$ iping

Consult ing fees

100

2

2

0

100

11

82
Breakdown of costs :$$
\text { consur }
$$

Total

Ratios:

Payback time : 13 years

Rate of return: $8.5 \%$
(*) Titane plate heat exchanger and degassing unit 


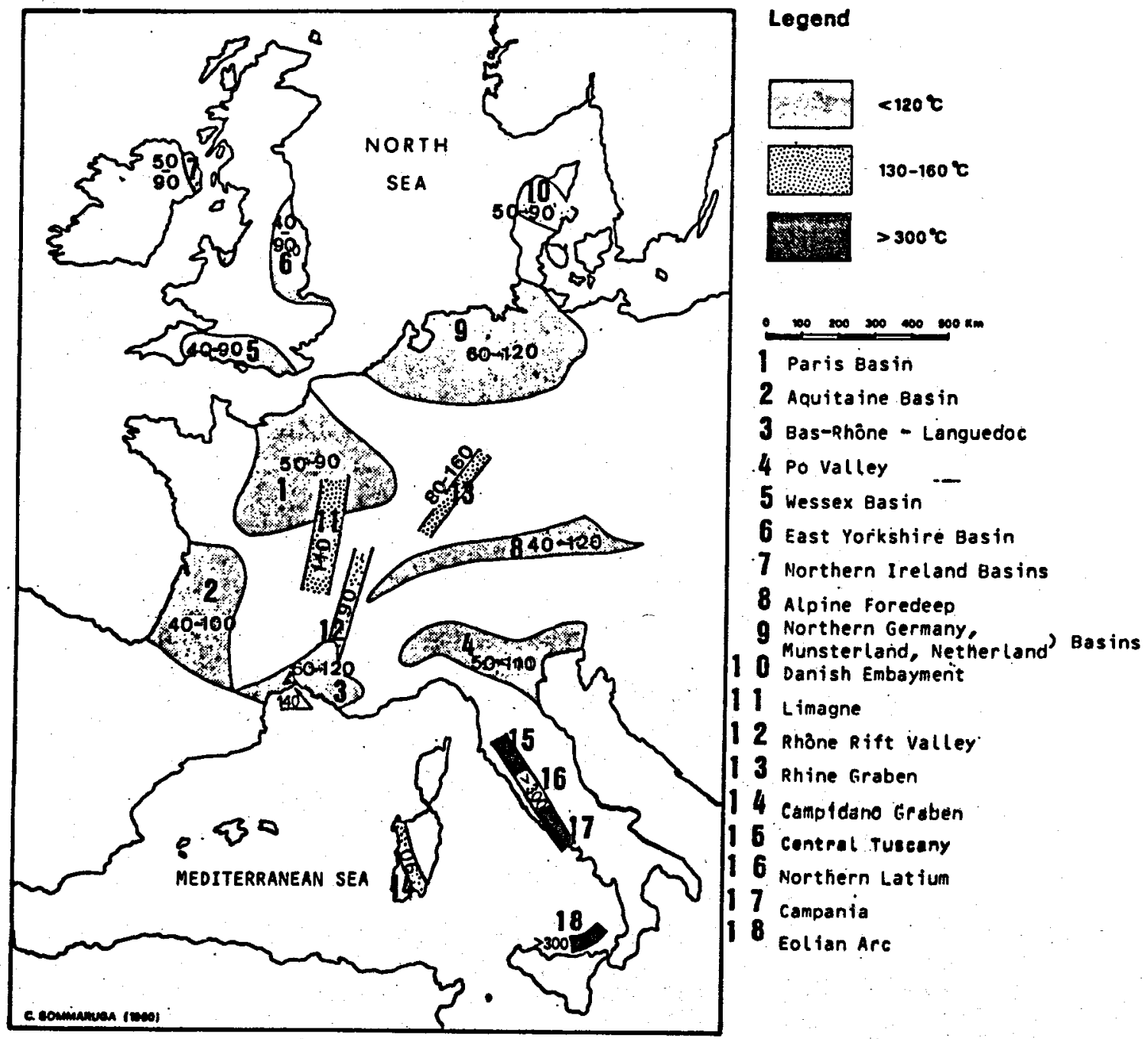

Figure 1 - An out line of EC geothermal resource status. Reservoir temperature range at depths varying from 1 to $3.5 \mathrm{~km}$ (after Sommaruga and Haenel) 

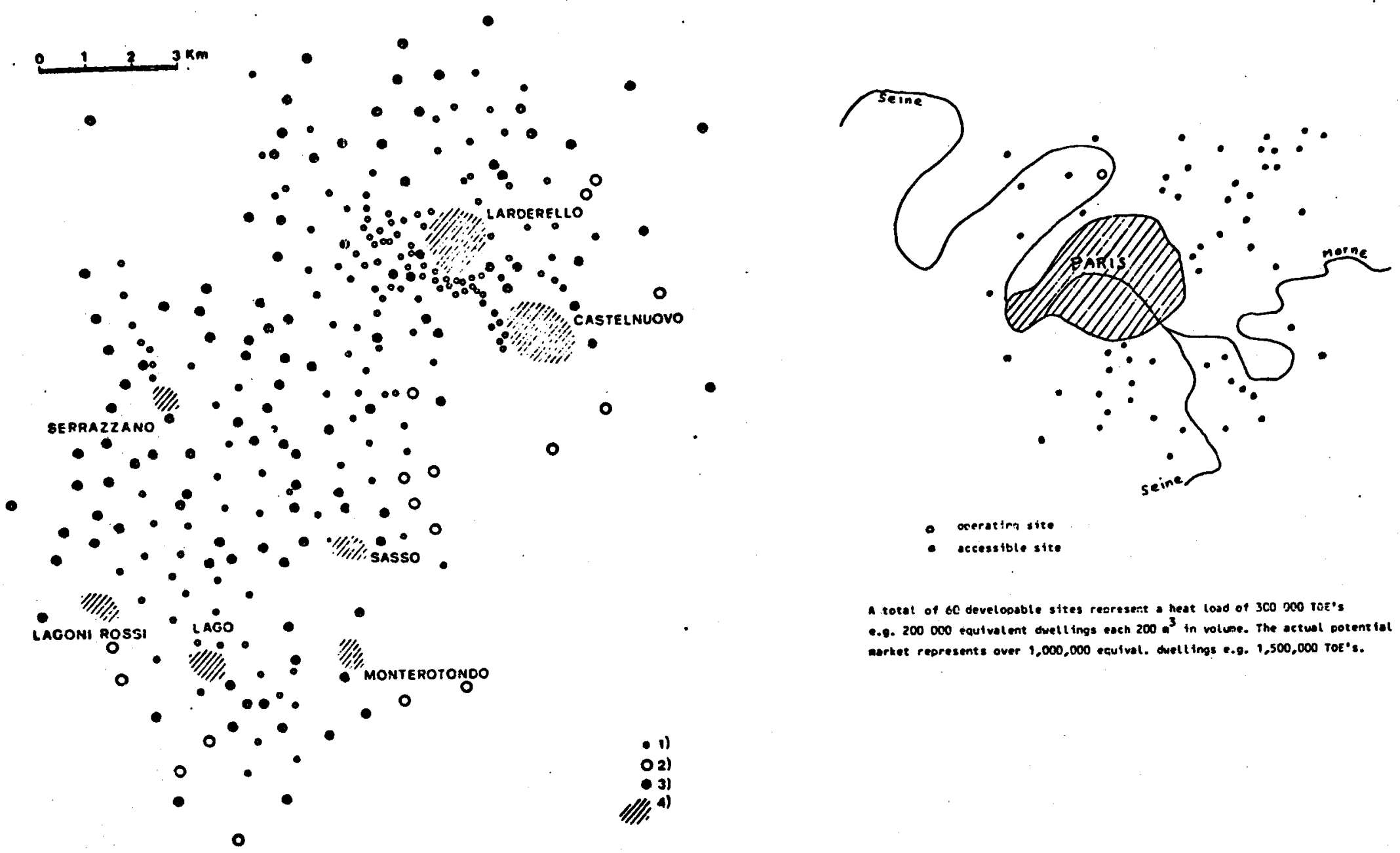

- ocerating sizo

accessible site

a. total of te developable sites reseresent a hest losd of 360 DeO iez's

C.9. 200 oco equivalent dwellings eoch $2000^{3}$ in volume. The actwal potenztat market represents over 1,000,000 equival. dwell ings e.9. 1,500,000 toE's.

Figure 2 - Larderello field. Well Location map (after ENEL)

1) Productive well

2) Non productive well (Low temperatures)

3) Dry hole or poor producer

4) Densely drilled area
Figure 3 - Geothermal district heating opportunities in the Paris Suburbs (restricted to accessible sites) 


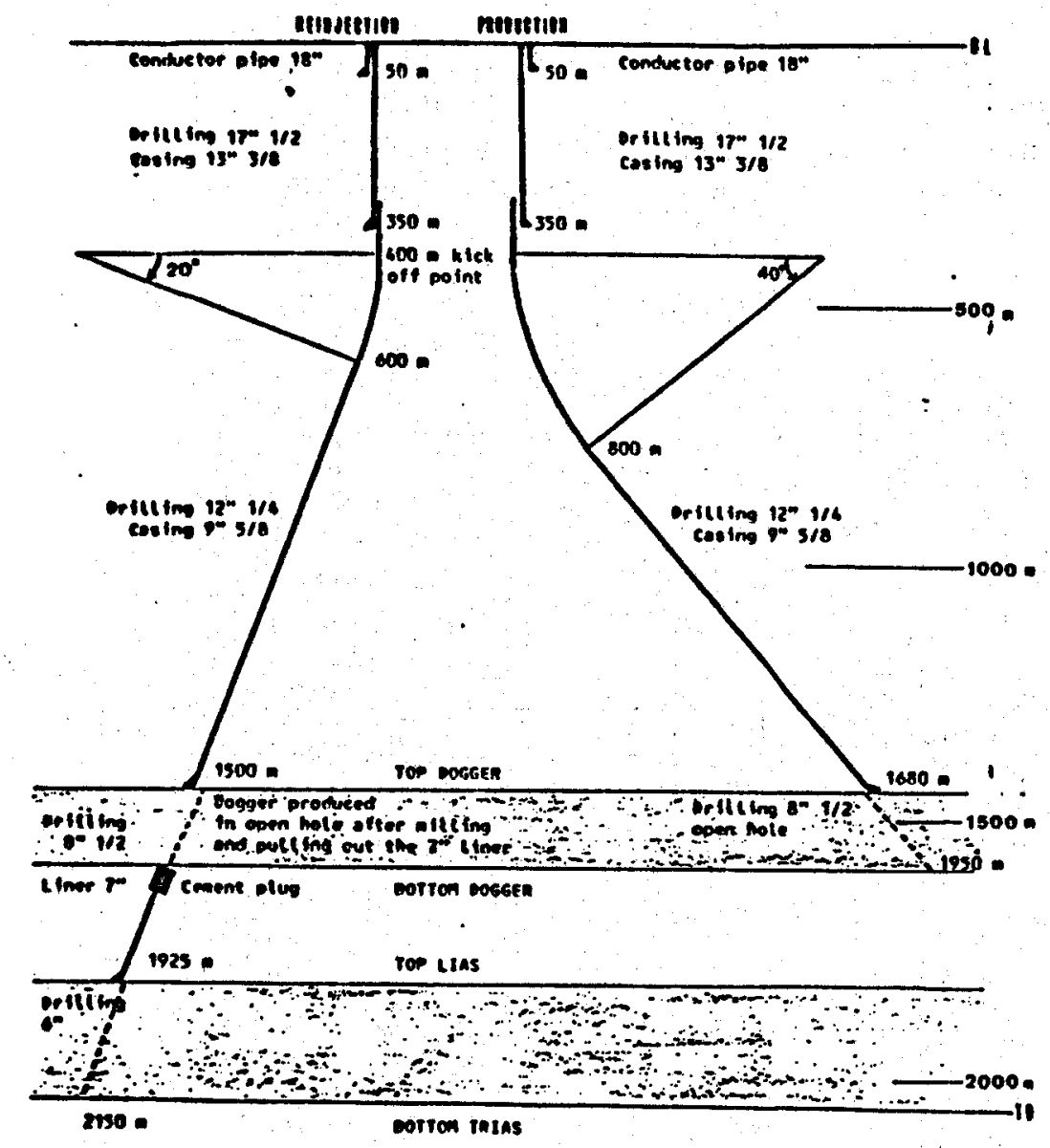

\begin{tabular}{|c|c|c|c|}
\hline & STAMPIAN & Fonta inebleau sands & LLISOEENE \\
\hline$\frac{1}{13}$ & $\begin{array}{l}\text { BARTUMIIAN } \\
\text { LUTETIAN VPAESIAN }\end{array}$ & Limestone, morl, sand and clay & COE E \\
\hline 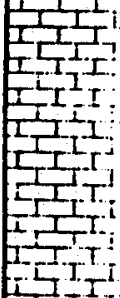 & $\begin{array}{l}\text { SEMONIAN } \\
\text { TUROMIAN } \\
\text { CEMOMANIAN }\end{array}$ & $\begin{array}{l}\text { Silex chalk } \\
\text { Grey chalk } \\
\text { Marly chalk }\end{array}$ & $\begin{array}{l}\text { UPPER } \\
\text { UPRETACEOUS }\end{array}$ \\
\hline 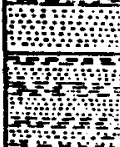 & $\begin{array}{l}\text { ALBIAN } \\
\text { APTIAN } \\
\text { BARREMIAN } \\
\text { NEOCOMIAN }\end{array}$ & $\begin{array}{l}\text { Clay and sand } \\
\text { glack clay } \\
\text { variegated sandstone clay }\end{array}$ & $\begin{array}{l}\text { LONER } \\
\text { CRETACEOUS }\end{array}$ \\
\hline 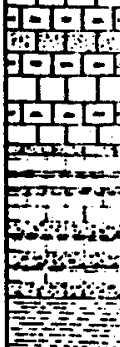 & $\begin{array}{l}\text { PUREECKIAN } \\
\text { PORTLANDIAN } \\
\text { KIMMERIDGIAN }\end{array}$ & $\begin{array}{l}\text { Alternating limestone } \\
\text { marls and sandstone } \\
\text { Limey serie with } \\
\text { interbedded marl } \\
\text { Black mart }\end{array}$ & MALM \\
\hline 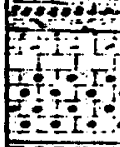 & $\begin{array}{l}\text { CALLOVIAN } \\
\text { GATHONIAN } \\
\text { BAJOCIAN } \\
\text { AALEGIAN }\end{array}$ & $\begin{array}{l}\text { Marls. oolitic reference } \\
\text { Gravetly and oolitic limestone } \\
\text { Zoogenic arl }\end{array}$ & DOGGER \\
\hline 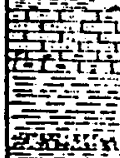 & $\begin{array}{l}\text { TOARCIAAT } \\
\text { PLIENSBACHIEN } \\
\text { SINEAMURIAN } \\
\text { HETTANGIAN }\end{array}$ & $\begin{array}{l}\text { Black pyritic mart } \\
\text { Alternating marl and dolomite }\end{array}$ & LIAs \\
\hline 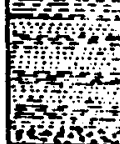 & $\begin{array}{l}\vdots \\
\text { RHETIC } \\
\text { KEUPER }\end{array}$ & $\begin{array}{l}\text { Clayey sandstone } \\
\text { pine grained santstone and } \\
\text { conglomerate }\end{array}$ & TRIAS \\
\hline & BASEMENT & sehist & PALEOLOLC \\
\hline
\end{tabular}

\footnotetext{
Fig. 4 - Multi aquifer reconnaissance. Drilling and well design (after Geoservices Hydrologie)
}

Fig. 5 - Synthetic lithostratigraphic log in the centre of the Paris Basin 
LE MEE/SUR SEISE (FRANCE)

CAMM MAT BOREHOLE GEONETRY LOC

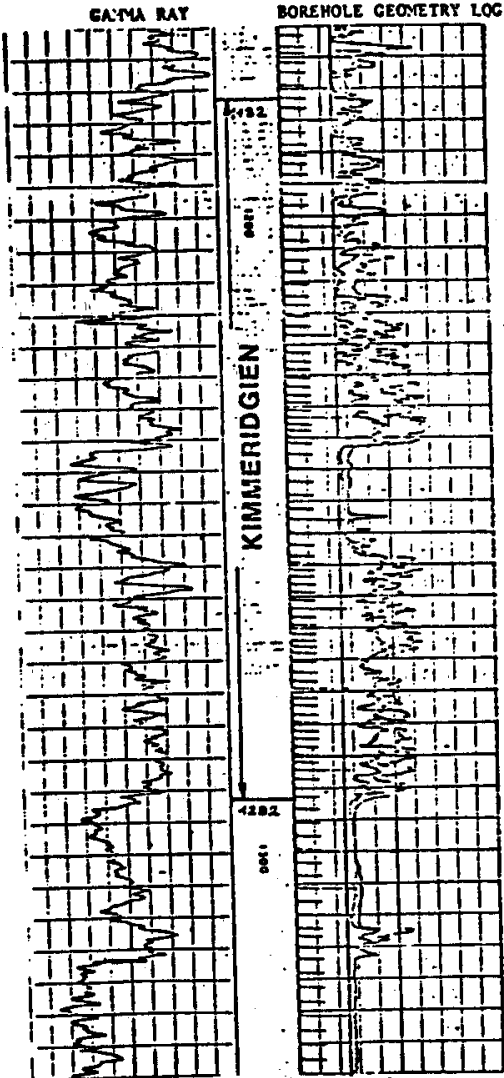

Bentonitic mud
YONTGERON (FRANCE)

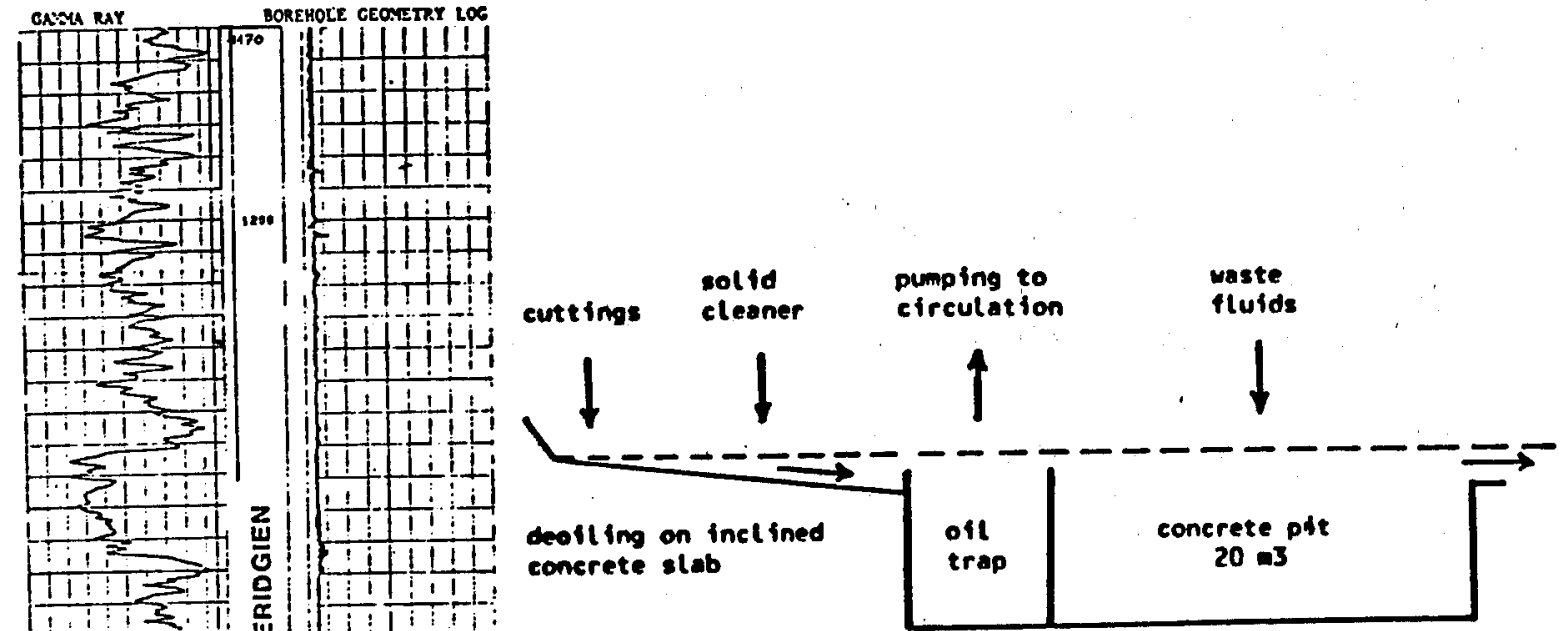

towards separator

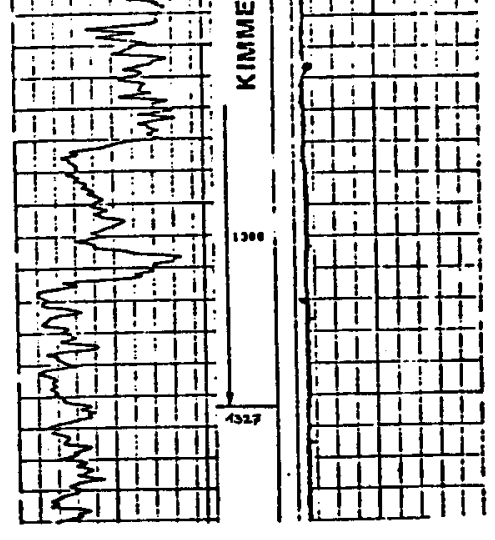

oil based mud

Fig. 6 - Borehole geometry. Comparison between two geothermal well bores drilled with Fig. 7 - simplified mud circuit (after Vathaire et al) a conventional bentonitic and oil based muds (after Geoservices Hydrologie) 


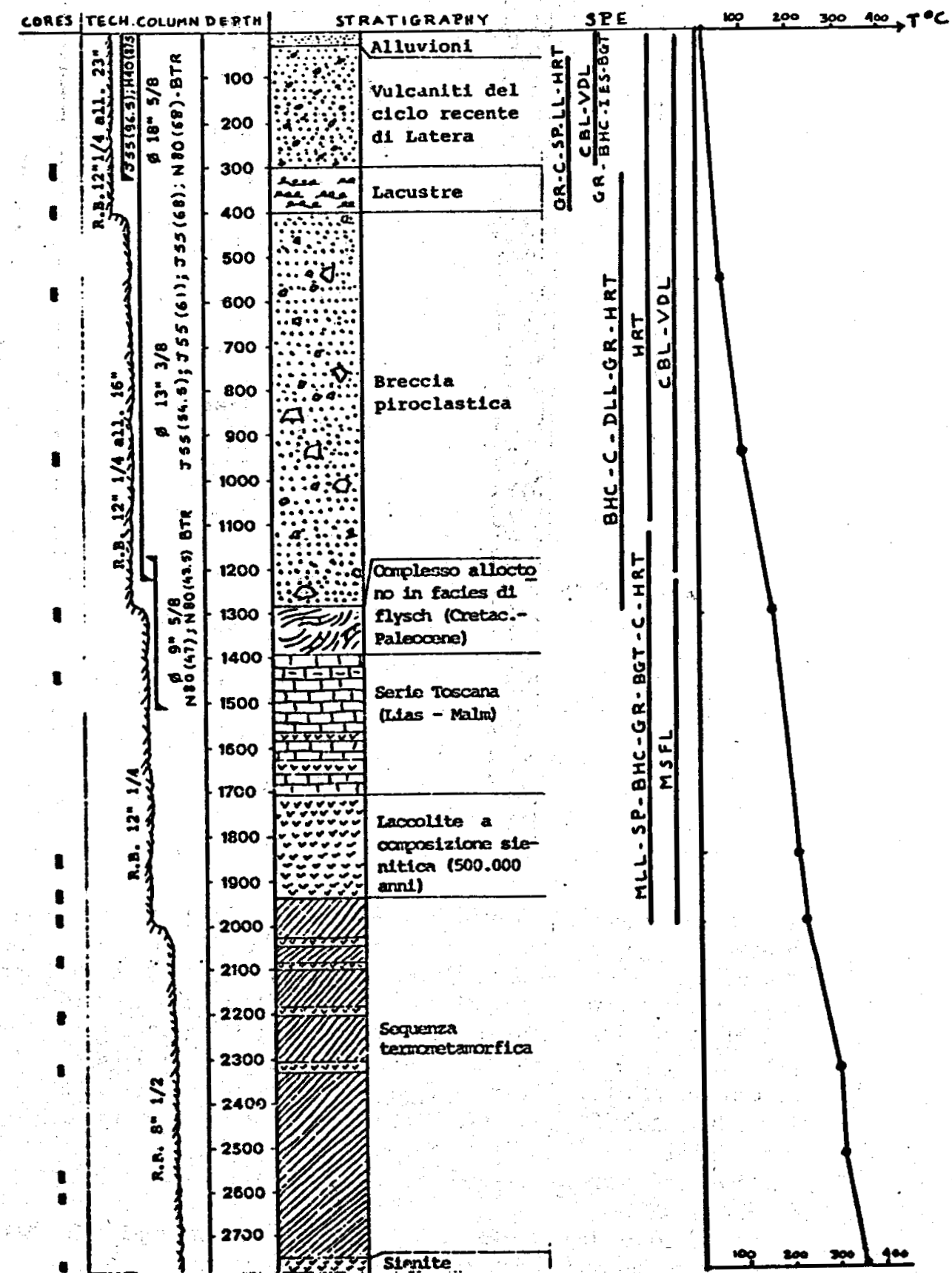

Fig. 8 - Latera Well logs (after ENEL) 


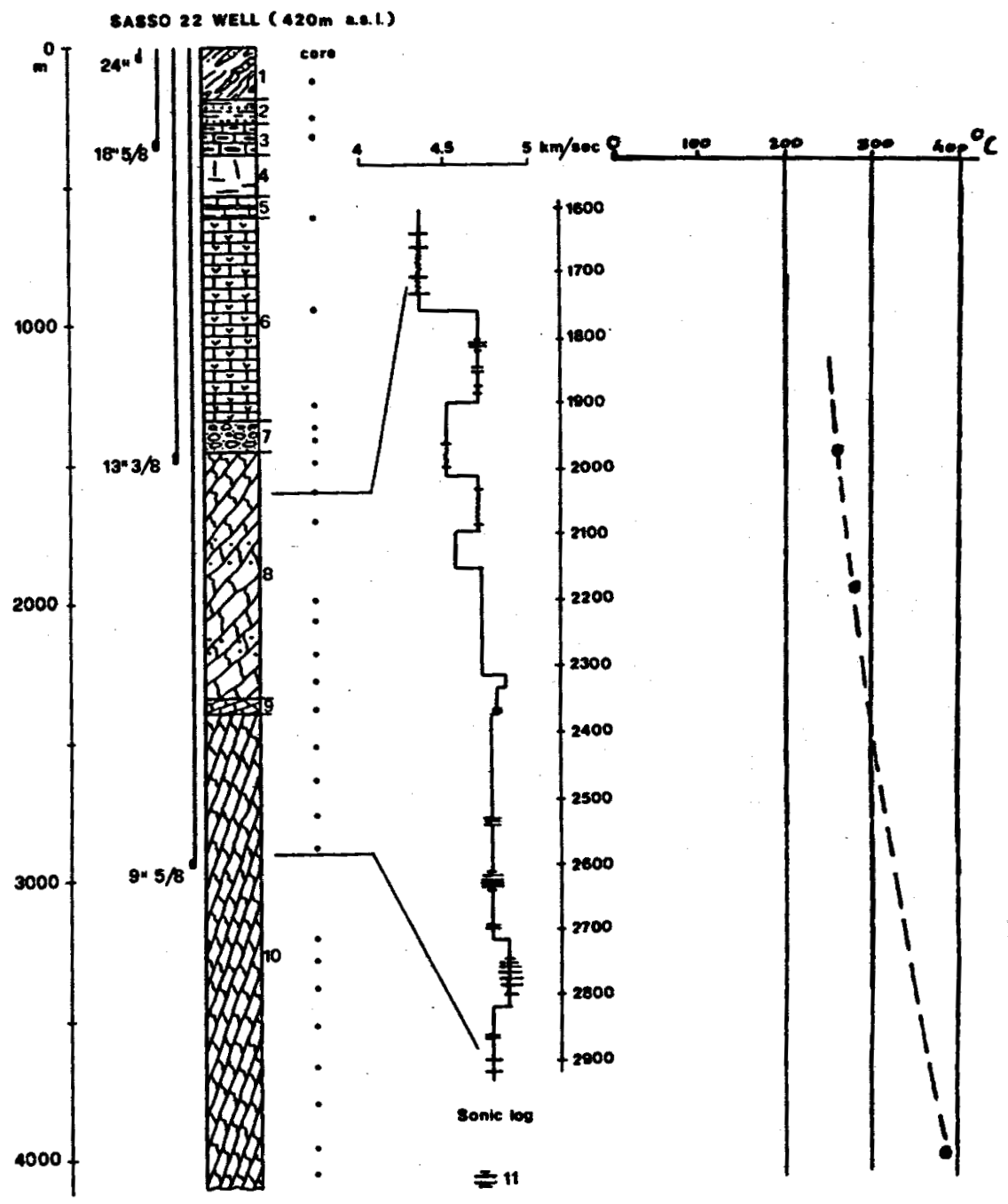

1) Eocenic Ligurian Nappe:flysch sequence of shaley and sandy sediments. 2)Oligocenic sandstone ('macigno') .3) Stratified cherty limestone.4)Massive limestone. 5) Marly dolostone. 6) Carbonate and anhydrite (Burano Formation). 3) to 6) are of Mesozoic age. 2) to 6) belong to the Tuscan Nappe. 7) Triassic slightly metamorphic quartz pebble conglomerate and coarse quartz-arenite (basal levels of the Tuscan Verrucano) . 8)Quartzite, phyllite, metagreywacke, metabasite of Lower Paleozoic'Filladi inferiori'Group. 9) Garnet-bearing plagioclase micaschist (Lower Paleozoic-Pre-Cambrian?). 10)Fine-grained gneisses and thin interbedded anphibolite levels (Lower PaleozoicPre-Cambrian?).

Processed sonic $10 \mathrm{~g}$ on the right refers to the interval $1600-2900 \mathrm{~m}$ of the basement. 11) Higher permeability horizons.

Fig. 9 - Well Sasso 22. Lithostratigraphic, sonic and temperature logs (after ENEL) 


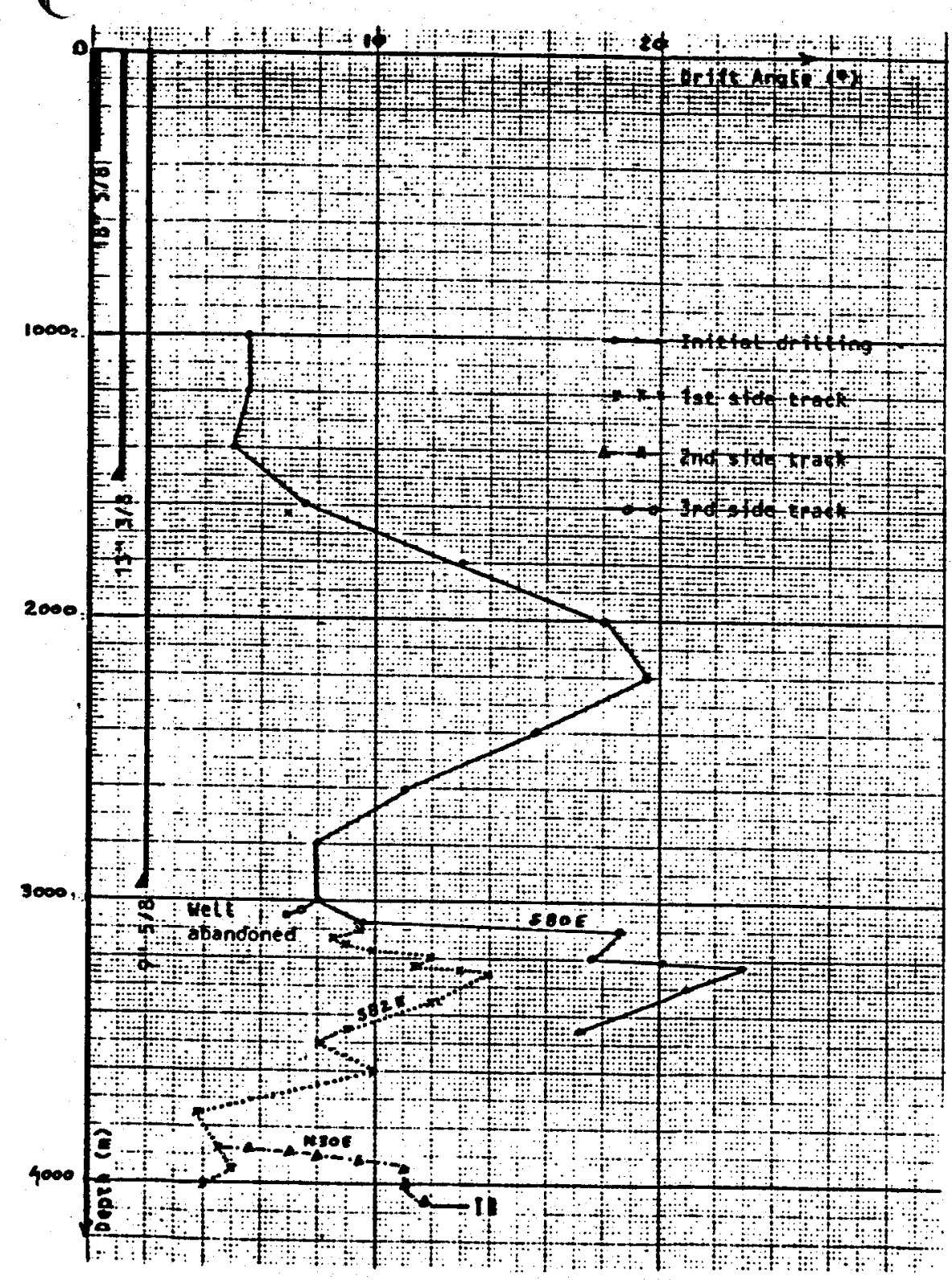

Fig. 10 - Sasso 22 Well. Verticality log

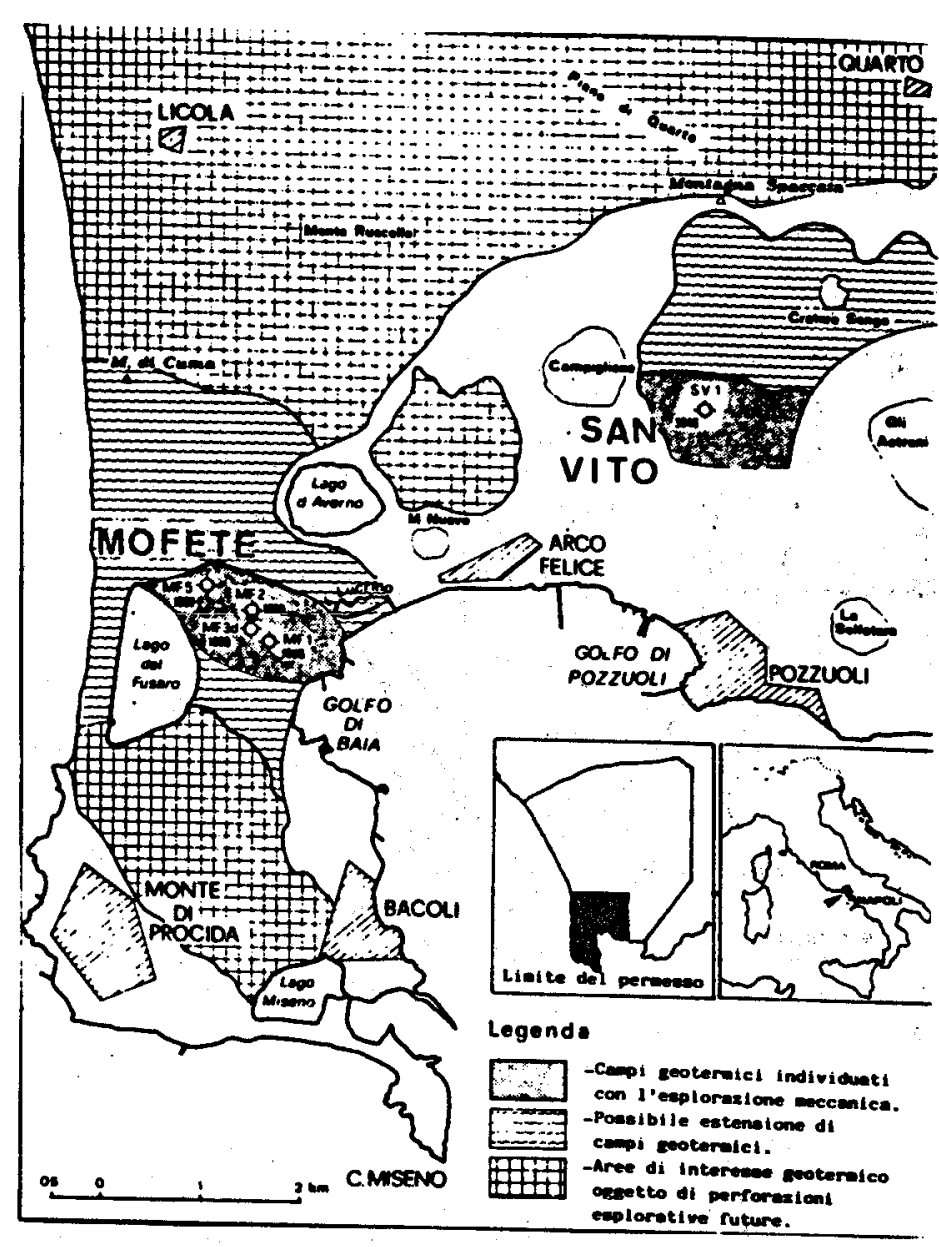

Fig. 11 - Phlegreaen Fields. Location map 


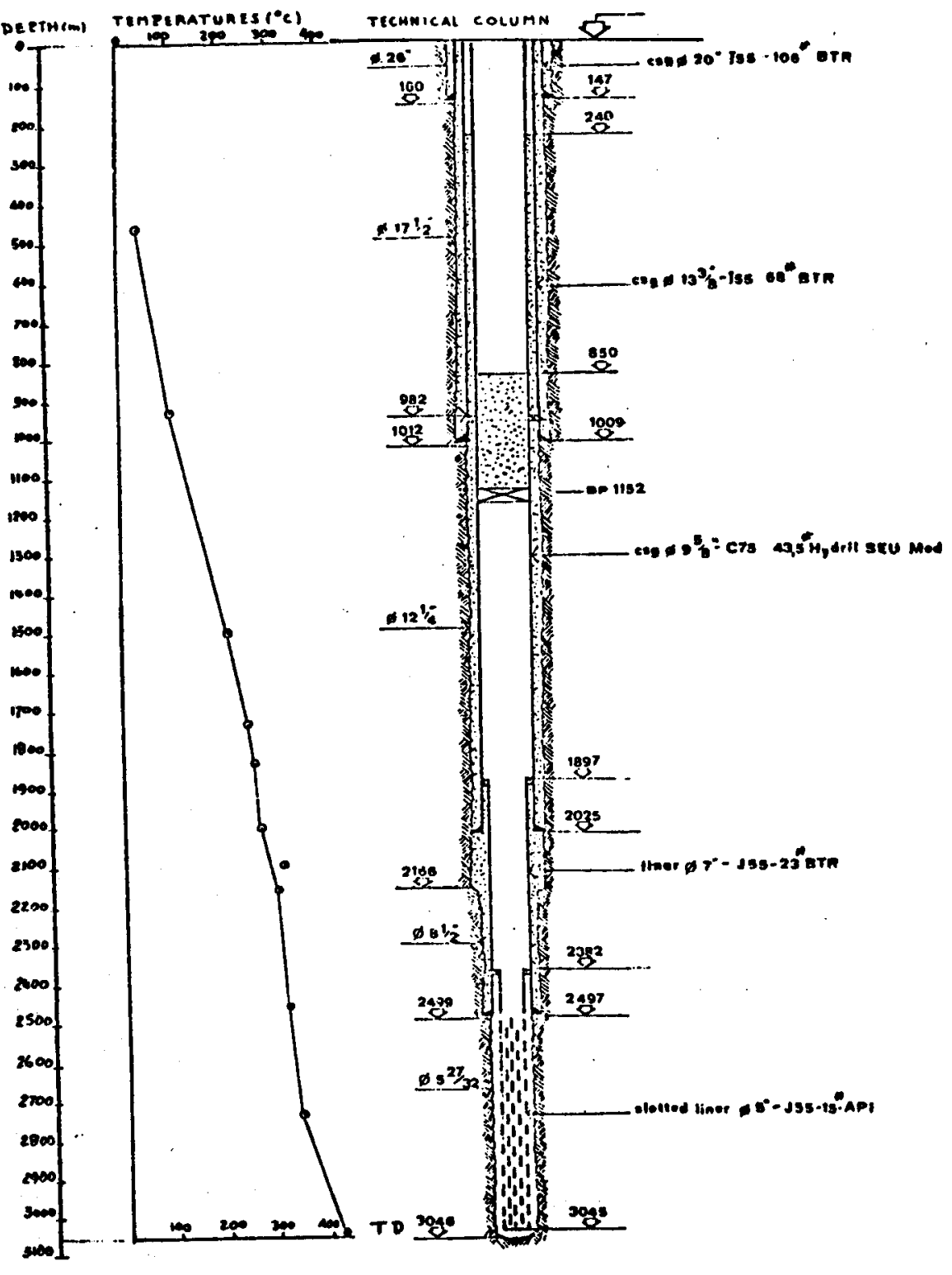

Fig. 12 - san Vito well logs (after AGIP)

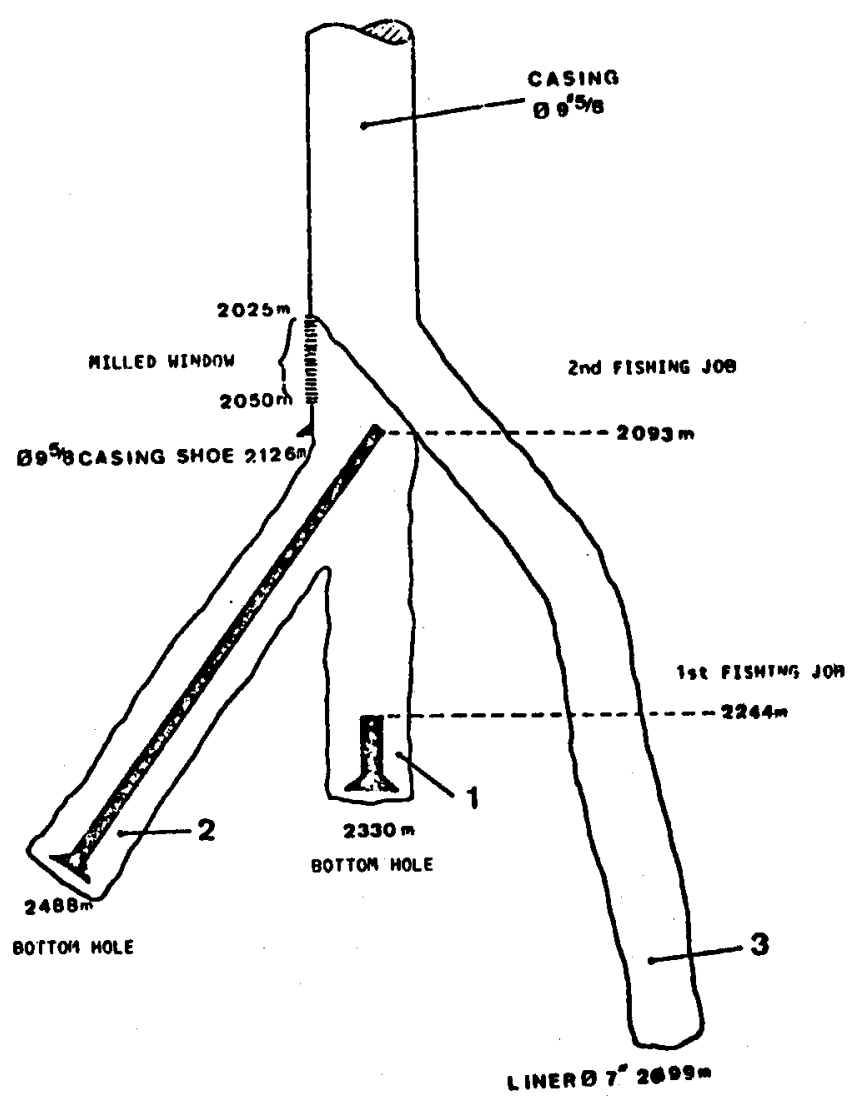

Fig. 13 - San Vito well. Side tracks (after AGIP) 